Uldaho Law

Digital Commons @ Uldaho Law

Articles

Faculty Works

2002

Joint Teaching with a Colleague, for Just a Week or Two

Richard Henry Seamon

Follow this and additional works at: https://digitalcommons.law.uidaho.edu/faculty_scholarship

Part of the Legal Education Commons 


\title{
Joint Teaching with a Colleague, for Just a Week or Two
}

\author{
Richard H. Seamon and Stephen A. Spitz
}

Law school isolates the subject matter of the law into separate courses, isolates law students into individual grade seekers, and isolates law teachers into classroom monarchs. In the practice of law, however, isolation is the exception, not the rule. The work of lawyers, unlike the education of lawyers, depends on collaboration and cooperation across specialties.

This article offers a modest alternative to the isolation found in law school classrooms. We describe a yearly series of about ten classes in which Seamon, who regularly teaches Constitutional Law, and Spitz, who regularly teaches Property Law, blend their classes to team-teach a topic that has a solid footing in each course: the law applicable to governmental takings of private property for public use.

We decided to make our yearly joint teaching efforts the subject of an article for three reasons. First, not much has been published on joint teaching in law school.' The little that has been published is about projects more ambitious than ours, which are often hard to replicate. Second, and relatedly, we believe that joint teaching benefits the students as well as the teachers, but the benefits are modest and may not get the attention they deserve. Third, because our joint teaching effort is relatively easy to implement, we believe it may appeal to law teachers who, like us, prefer low-risk attempts to improve their teaching.

Richard H. Seamon <seamon@law.law.sc.edu> and Stephen A. Spitz <Steves@law.law.sc.edu.> are associate professors of law at the University of South Carolina.

We thank all of the students who have participated in the classes described in this article, with special thanks to Natalie E. Byars and John P. Works, members of U.S.C.'s law school class of 2003, who not only sat through our joint classes but also gave us some valuable ideas for this article. We thank as well the editorial consultants to the Journal of Legal Education for their valuable suggestions.

1. More has been published about team teaching in higher education generally. Discussing empirical support for the value of team teaching, Rebecca S. Anderson and Bruce W. Speck have noted that "the literature on team teaching in higher education offers a positive appraisal of [it]." "Oh What A Difference A Team Makes": Why Team Teaching Makes a Difference, 14 Teaching \& Tchr. Educ. 671, 671 (1998). See also Ann E. Austin \& Roger G. Baldwin, Faculty Collaboration: Enhancing the Quality of Scholarship and Teaching 41 (Washington, 1991); Sherry E. Sullivan, Are Two Heads Better Than One? An Empirical Examination of Team Teaching, 25 C. Student J. 308 (1991); Timothy G. Hatcher et al., Graduate Students' Perceptions of University Team Teaching, 30 C. Student J. 367 (1996). 
The following sections of this article describe how we blend our classes, what the blending seems to accomplish, and what we recommend to teachers who want to try something similar.

\section{Description of the Blended Classes}

The two courses that we teach, Constitutional Law and Property Law, are in the first-year curriculum at our school. Students in the first-year class are assigned to one of three sections. We have arranged to teach the same section of first-year students in each of the last several years. Each year, during two weeks near the end of the first semester, we have spent about ten class sessions jointly teaching students about the law applicable to governmental takings of private property for public use, or the law of takings. ${ }^{2}$

We call them blended classes because they meet during the times regularly scheduled for Property and Constitutional Law but are sequential. Suppose, for example, that on Monday mornings Property meets at nine o'clock and Constitutional Law at eleven. For the two weeks of blended classes, both of us will attend both classes, and the eleven o'clock session will pick up where the nine o'clock session ended. This means, of course, that both of us teach "extra" classes. We tell the students that we enjoy this opportunity to spend additional time with them and with each other in a professional setting, and to do something that cannot be done in the "normal" law school classroom.

\section{A. Before the Blended Classes Begin}

Law professors need a game plan for every course they teach, and law students need to know that the teacher has a game plan. ${ }^{3}$ The need to spell out the game plan to students is especially strong when the teacher plans to do something unconventional. At our law school, team teaching falls into the "unconventional" category. Accordingly, we each start the semester by preparing our students for the two weeks of blended classes. As the two weeks approach, we give the students additional information. Our objectives are to help the students understand how these "special" classes fit into each course and to encourage them to become curious and eager to begin them.

\section{Advance Preparation in the Course Syllabi}

The advance preparation begins with the syllabus for each course. In our syllabi we relate the law of takings to the subject matter of each course as a whole and explain why we are teaching this subject jointly.

2. We have blended our classes during the first semester because that is when Constitutional Law has been offered at our school for the past several years, as a one-semester, four-credit course. Property Law has been a two-semester, six-credit course for first-year students. But our first-year curriculum was recently revised, so that Constitutional Law will now be offered only in the second semester of the first year. We will be interested to see if our moving the blended classes from the first semester to the second semester will have any effect.

3. Research shows, as common sense suggests, that students learn better when the teacher tells them, up front, what they are supposed to learn in the course as a whole as well as in particular class sessions. See, e.g., Jay Feinman \& Mark Feldman, Pedagogy and Politics, 73 Geo. L.J. 875, 898-99 \& n.55 (1985); Kent D. Syverud, Taking Students Seriously: A Guide for New Law Teachers, 43 J. Legal Educ. 247, 249 (1993). 
Seamon's syllabus relates the subject matter of the blended classes to the subject of constitutional law as follows:

In this course, you will learn primarily about three aspects of government under the U.S. Constitution: (1) the powers of, and the relationships among, the three branches of the federal government; (2) the powers of the States; and (3) the relationship between the federal government and the States. You will also learn about one of the individual rights protected by the U.S. Constitution: the right to just compensation when the government takes private property for public use.

The syllabus then explains that other individual rights are explored in an upper-level course called Individual Liberties. Thus the syllabus identifies the law of takings as involving one of the individual rights that the Constitution protects from government interference.

Spitz's syllabus for Property similarly relates the law of takings to the overall subject of property. It states that one of the main subjects of property law is the transfer of land from one person or entity to another. It explains that such transfers can be either voluntary or involuntary, and that one example of an extremely important-and sometimes quite controversial-involuntary transfer occurs when the government takes property from a private owner for public use.

The Property syllabus also provides other information about the blended classes: it identifies the two weeks during which the joint classes will occur, and it relates the blended classes to one of the course's primary objectives:

The fifth and final objective of this course relates to the joint classes with your Constitutional Law section. Property does not exist in isolation. In fact, much of the property law you will study this year is really contract law (real estate contracts) or constitutional law (regulatory takings doctrines) or administrative law (zoning). When you study both constitutional law and property law from two different perspectives, and from two different textbooks, you will learn more about the interconnections between Property and other courses.

After teaching the blended classes for a year or two, we came to realize that our syllabi needed to address another issue, of great importance to students: how would they be tested on the jointly covered material? Both of our courses, like most first-year courses, grade students primarily on the basis of a final exam. We concluded that both syllabi had to advise the students explicitly, in each class, which course's exam would cover the joint material. (More about this later.)

\section{Advance Preparation in the First Week of Classes}

Each of us uses at least one entire class session in the first week of the semester to give students an overview of the course. As part of that overview we reinforce and supplement the material about the blended classes that is presented in the syllabi. We also try to generate in the students some suspense and excitement about those classes. ${ }^{4}$

4. The idea that teachers might even square off and become subject to questions from their own students and another teacher is such a novel idea in our law school that it in inerently interesting to many students. 
In the first week of Constitutional Law, Seamon gives students a "functional definition" of the U.S. Constitution and links that definition to the law of takings. According to the definition, the Constitution serves three functions: it establishes a national government; it establishes ground rules for relations between the national government and the states and for relations among the states; and it protects certain individual rights from interference by the national government or the states. Seamon explains that most of the course examines the first two functions, but students will be introduced to the third function through the study of one of the individual rights protected by the Constitution: the right to receive just compensation when the government takes your land for public use.

In the first week of Property, Spitz similarly tries to fit the law of takings into an overview of his course. At our school Property is a two-semester, six-credit course; it covers the standard subjects of personal property, estates, landlordtenant law, easements and covenants, land use regulations, and governmental takings law. Spitz spends some time in the first week explaining that one part of the course, involving the chapters titled "Condemnation" and "Regulatory Takings," is material that the class will be reading and studying in both his and Seamon's course.

In the first week we each explain that the law of takings can be studied from both a constitutional law and a property law perspective. We try to make this point humorously. Seamon may tell the class: "Professor Spitz likes to think that the law of takings is really a property law topic. Between you and me, though, it's really a constitutional law topic." Spitz tells the very same class, usually on the same day, "Professor Seamon likes to think that the law of takings is really a constitutional law topic. Between you and me, of course, he is in error; this is clearly a property law topic." Each of us proceeds to admit, more seriously, that the topic can be seen from either perspective, as the students will learn in the joint classes. ${ }^{5}$

\section{Advance Preparation After the First Week of Classes}

Once the semester is underway, we each use the law of takings to help students learn how property law connects to constitutional law and, by extrapolation, how other seemingly discrete bodies of law interconnect.

We find that many students think of property law and constitutional law as opposites. To them, property law is tangible ("It's about dirt"); it is local law, varying from state to state; and it concerns itself solely with private disputes. By contrast, they see constitutional law as abstract, national, and governmental. These differences initially make it quite hard for students to see connections between the two subjects.

5. As merely one ongoing-clearly trivial-example of just how much fun it has become to jointly teach this material (and, by extension, jointly write this article) Seamon labeled each of his drafts of this article "conprop.art" on his computer. Of course, as Spitz sees the matter, Seamon is all wrong, and Spitz accordingly has corrected this mislabeling on his computer by calling the article "propcon,art." In the end we compromised, and on both computers we labeled the article "lawteaching,art." 
Even before we study the law of takings in depth, we use it to help students begin to appreciate the connections between constitutional law and property law. Early in the Constitutional Law course, for example, students study cases in which the U.S. Supreme Court distinguishes the enumerated powers of the federal government from the "police powers" of the states. ${ }^{6}$ Students often have trouble understanding what the Court means by "police powers." They can begin to understand the concept if the teacher cites as an example of those powers the local regulation of land use. ${ }^{7}$ The teacher can also promise students that the concept of police powers will be further explored in the blended classes on the law of takings. In this way, a property law subject (land use regulation) brings a constitutional law subject (the police powers) down to earth.

By the same token, references to the law of takings in the Property course can help students put that subject into a broader context. Early in the first semester Spitz teaches "adverse possession," a concept that many students initially think is akin to "stealing" the rightful owner's land. Spitz and the students talk a lot about the policy reasons behind this type of involuntary transfer. A natural extension is to then discuss another type of involuntary transfer that the class will be studying later in the semester: the government's use of eminent domain to take private property for public use. As part of this discussion, Spitz poses the question "Why should government be granted the power to take private land for public use?" This can provoke yet another important question: whether government itself can engage in "adverse possession" and thus avoid the constitutional mandate of fair compensation. This discussion nicely connects an early part of the semester with topics to be explored later on.

In addition to using the substance of the blended classes to help students learn the substance of each course, we try to sensitize students to the collaboration process. It so happens that our personalities and backgrounds differ in ways that quickly become apparent to our students. Specifically, Seamon comes across as a highly organized button-down kind of guy who, as a former government lawyer, can often speak from the government's perspective. ${ }^{8}$ Spitz is a more spontaneous, gregarious sort who spent much of his legal practice representing private land owners. ${ }^{9} \mathrm{He}$ can speak convincingly from the landowner's perspective. In the weeks before the blended classes begin, we play up these differences to generate humor and suspense about how we will work together. As a result, the students seem eagerly to anticipate seeing us team-teach.

6. See, e.g., Willson v. Black Bird Creek Marsh Co., 27 U.S. (2 Pet.) 245, 252 (1829).

7. See, e.g., Village of Euclid v. Ambler Realty Co., 272 U.S. 365, 389-90 (1926).

8. Seamon wrote the sentence in the text, and in this footnote Spitz must express his strong dissent. With all due respect, Seamon has been voted the outstanding professor of the year several times at U.S.C. Law School, so the students see him as anything but a "button-down" type of guy - whatever in the world that phrase may mean.

9. Seamon wrote this sentence in the text too. In this footnote Spitz must admit that he is known for spending far too much time with students in the lobby of the law school (as virtually the entire law school will attest), and, while gregarious is one word for this activity, other less attractive words (endless delay) also come to mind. 


\section{B. During the Blended Classes}

\section{Organization and Substance}

We structure the ten blended classes to have a beginning, a middle, and an end. The first class introduces the law of takings. The next eight classes explore two types of takings: eminent domain and regulatory takings. The last class has a real twist: we present an oral appellate argument to a panel of student judges in a regulatory takings case. ${ }^{10}$

The first blended class session looks both backward and forward. Looking backward, we relate the law of takings to the subjects of constitutional law and property law as a whole. Sometimes we have done this by taking turns explaining why the law of takings is really a topic that belongs in my course: Seamon explains why it is really a constitutional law topic, and Spitz explains why it is really a property law topic.

Each explanation refers to a formula written on the chalkboard:

governmental taking + private property + public use = just compensation

Seamon emphasizes that this formula is prescribed in the Constitution and illustrates one of the primary functions of that document: to protect private rights against government interference. Spitz emphasizes that the constitutional command of just compensation depends on the existence of a property right under state law.

We use the same formula in the first blended class to describe what the blended classes will cover. ${ }^{11}$ We explain that with our first topic, eminent domain, there is typically no dispute that "private property" has been "taken"; instead, disputes usually are about what compensation is "just" or (occasionally) whether the taking is for "public use." We go on to explain that, outside of the eminent domain setting, disputes arise about whether government action constitutes a "taking"; the most common form of that sort of dispute concerns government regulations of the use of property-hence the term "regulatory takings."

The next three blended classes concern eminent domain. In the first, students learn the basic operation of the South Carolina Ëminent Domain Procedures $\mathrm{Act}^{12}$ and get some practice in reading statutes. In the second, they watch a documentary on a controversial use of the eminent domain power by the City of Detroit, which exercised that power in the early 1980s to get land

10. Students at our law school have heard about the blended classes from other students and clearly look forward to them. In the academic year during which this article was prepared, Seamon was visting at Washington and Lee. So, for the first time, Spitz taught the blended classes with another teacher at South Carolina, Herbert Johnson. The blended classes were structured a little differently. Johnson and Spitz spent one week instead of two teaching jointly, and the series of blended classes did not end with an oral argument between the teachers but instead with a series of oral arguments by several student "law firms" against each other, with other students sitting as judges. Nonetheless, the concept was essentially the same-and this points out how adaptable it is.

11. If you are interested in any of the handouts that we use in this part of the joint courses, please do not hesitate to write or e-mail us; we would be happy to send you additional information.

12. S.C. Code Ann. $\$ \S 28-2-10$ through 28-2-510. 
for a General Motors plant in a neighborhood once called Poletown. ${ }^{13}$ In the third class students discuss the policy questions raised by the Poletown case. Every year this third session has been an extraordinarily lively discussion, turning on questions of both property law and constitutional law. ${ }^{14}$ It helps to have a property expert and a constitutional law expert in the same classroom coordinating these discussions. Also in the third class we discuss the relationships between federal constitutional provisions, state constitutional provisions, and state statutory provisions. ${ }^{15}$

Our study of eminent domain is followed by four blended classes on regulatory takings. We almost always use cases from both textbooks to demonstrate that the subject matter partakes of both constitutional law and property law. ${ }^{16}$ These classes focus on major cases decided by the U.S. Supreme Court and offer numerous opportunities to discuss property law issues in the context of constitutional analysis. They provide a natural vehicle for our joint teaching: each of us draws on the other's expertise while in front of the class. ${ }^{17} \mathrm{We}$ use the Court's opinions in these cases to construct a flowchart for identifying and analyzing regulatory takings.

In the penultimate blended class we examine two classic Supreme Court cases: Miller $v$. Schoen $e^{18}$ and United States $v$. Caltex. ${ }^{19}$ To introduce them, we

13. Poletown Lives! (Information Factory 1982). This documentary is based on Poletown Neighborhood Council v. City of Detroit, 304 N.W.2d 455 (Mich. 1981), a case found in a number of standard property textbooks.

14. This discussion naturally leads to further discussion of cases such as Berman v. Parker, 348 U.S. 32 (1954) (upholding use of eminent domain for "slum" clearance), a case often found in either Spitz's Property text or Seamon's Constitutional Law text (or both). Berman, in turn, leads naturally to Penn Central Transportation Co. v. New York City, 438 U.S. 104 (1978) (upholding regulation to preserve historic structures), another case with a foot in both property law and constitutional law.

15. The Poletown case is a good vehicle for helping students understand that a governmental action-in that case, Detroit's condemnation of Poletown-can be challenged on many grounds, including on es based on municipal law, state statutes, the state constitution, and the federal Constitution.

16. The cases that we usually use (in the order in which we usually use them) are Village of Euclid, 272 U.S. $\$ 365$ (1926); Nectow v. Cambridge, 277 U.S. 183 (1928); Pa. Coal Co. v. Mahon, 260 U.S. 393 (1922); Penn Cent. Transp. Co. v. New York City, 438 U.S. 104 (1978); Loretto v. Teleprompter Manhattan CATV Corp., 458 U.S. 419 (1982); Yee v. City of Escondido, 503 U.S. 519 (1992); Lucas v. S.C. Coastal Council, 505 U.S. 1003 (1992); Dolan v. City of Tigard, 512 U.S. 374 (1994); Nollan v. Cal. Coastal Comm'n, 483 U.S. 825 (1987); Miller v. Schoene, 276 U.S. 272 (1915); and United States v. Caltex, 344 U.S. 149 (1952).

17. For example, the Court has held that the government must compensate owners for regulations that totally destroy the value of their property. See Lucas, 505 U.S. at 1019 . This holding makes it important to identify what counts as a property interest. See Tahoe-Sierra Preservation Council v. Tahoe Reg'l Planning Agency, 122 S. Ct. 1465, 1483-84 (2002) (discussing how to define property interest for purposes of applying "total taking" rule of Lucas).

18. 276 U.S. 272 (1928). In Miller the Court denied Julia Miller and others compensation when the Commonwealth of Virginia destroyed red cedar trees to protect nearby apple orchards. $I d$. at 277 . Because of a disease that was harbored by the cedar trees and destructive of the apple trees, one or the other type of tree had to go. The Court held that it was within the state's police power to make that decision, and to make it without compensation to the owners of the trees that were selected to be destroyed. $I d$. at 278-81.

19. 344 U.S. 149 (1952). In Calex the Court held that the federal government did not have to pay just compensation for oil terminal facilities that it had destroyed in the Philippines, at the 
explain that the regulatory takings flowchart that we distilled from prior cases identifies when governmental regulation will be equated with governmental appropriation. Miller and Caltex, in contrast, demonstrate that sometimes even government appropriation will not be treated as an appropriation that triggers a right to just compensation under the Constitution. We use these two cases primarily to stimulate discussion of the policies underlying the Just Compensation Clause and the Court's case law on regulatory takings. This approach gives students a change of pace from the doctrinal emphasis that characterized our prior examination of the case law.

In the final blended class we turn the normal law school form of the Socratic method on its head. In a class we call "reverse Socratic" the teachers, as lawyers, present an oral appellate argument in an actual regulatory taking case to a panel of nine student justices. In preparation for that class we select nine student volunteers to be justices and ask the entire class to read some background material. On the day of argument we pose to the students who are not playing judges several questions to consider during the argumentquestions designed to provoke critiques of the advocates and the judges. ${ }^{20}$ After the argument we discuss those questions, and the advocates and judges share their perceptions of the case and the argument with the class. We ask the judges to deliberate and deliver an opinion two or three days later. ${ }^{21}$

Within a week after the blended classes end, we distribute to our students an evaluation form on which we request their anonymous comments. We tell the students that their comments invariably help us improve the blended classes. We also tell them that we will not review their comments until after we turn in their grades for the two courses.

\section{Teaching Methods}

Like most U.S. law faculty, neither of us has had any formal training in how to teach. We therefore hesitate to prescribe specific methods for teaching the blended material. The methods that we have developed reflect two main impulses: a desire to mix it up by using a variety of methods, and a desire to help students experience a truly joint effort.

outset of World War II, to prevent the facilities from falling into enemy hands. Id. at 150-56. Justices Douglas and Black dissented. Id. at 156. When we teach Caltex in the blended classes, we often find that student opinion, just like that of the Court, is sharply divided.

20. Some examples of questions: What arguments were most convincing? least convincing? What arguments would you have made that were not made? What questions would you have asked if you were a judge?

21. Over the years, we have used one of two cases: Bennis v. Michigan, 516 U.S. 442 (1996), or Main v. Thomason, 535 S.E.2d 918 (S.C. 2000). In Bennis, local government forfeited a car that had been used by a man for an assignation with a prostitute. 516 U.S. at 443-44. The man co-owned the forfeited car with his wife, who had no knowledge of her husband's illegal activity. Id. at 443. The U.S. Supreme Court rejected the wife's "innocent owner" challenge to the forfeiture, which was based in part on the Just Compensation Clause. Id. at 452-53. In Main, the South Carolina Supreme Court upheld, against a challenge based on the Just Compensation Clause, a state law that allowed one landowner to enter his neighbor's property, over the neighbor's objection, if the entry was necessary to make repairs to the owner's house. Main, 535 S.E. 2d at 922-23. We use one of these cases because each of us was involved in one of them-Seamon in Bennis, Spitz in Main. 
The first impulse is fairly easy to act on because our material is varied and so are our objectives from class to class. We find the lecture method most appropriate for the introductory blended class. In the class on the eminent domain statute, we most recently had a guest practitioner do a PowerPoint presentation. In the class after the Poletown documentary, we initially pose policy-oriented questions to generate student discussion; we end the class, however, by discussing statutory provisions governing the purposes for which eminent domain can be exercised and by summarizing the black letter constitutional law on the subject. In classes on Supreme Court case law, we use a quasi-Socratic questioning method to help students construct a framework for analyzing regulatory takings. ${ }^{22}$ The final class is essentially a simulation exercise.

We have developed ground rules to help us come across as a team. In each class session we regularly alternate taking the lead, so neither of us dominates any session..$^{23}$ While one takes the lead, the other stays alert to interject appropriate questions and comments. We share responsibility for responding to student questions and comments.

We find that students often benefit from hearing two teachers' responses. For example, a student who wants something clarified can find it useful to hear two differently phrased explanations. At the same time, we find it essential to be consistent with each other, especially in matters of black letter law. Students understandably get frustrated if they believe that they are being told two different versions of The Rules. On the flip side, the students enjoy hearing two conflicting professorial perspectives on a matter that is obviously in a gray area. We believe that presenting our differing perspectives helps the students feel more comfortable disagreeing with their teachers.

\section{Assessment of Students' Leaming}

Each of our courses ends with a final exam that is the main determinant of the students' grades. We take turns testing the blended material. Seamon tested the blended material on his Constitutional Law exam in fall 1999; Spitz tested the blended material on his Property Law exam in fall 2000. Before the blended classes begin, we tell the students which of us will test the material that year. After the blended classes end, students typically pose their questions about the material to whichever of us will be testing it (though we don't require that).

\section{Apparent Benefits of Joint Teaching}

We began teaching jointly because we thought it would be fun for us and our students. We quickly identified two objectives in addition to having fun: to help students bridge the curricular divide between two separate courses, and

22. We call our method quasi-Socratic in recognition that the so-called Socratic method prevalent in law school classrooms differs from Socrates' method of inquiry.

23. This is something to be particularly careful about. Students often try to find hidden meanings between the teachers, so you need to be extra careful that both teachers are given equal opportunities to chat about their specific perspectives. 
to model collaborative skills. Judging from student evaluations, we seem to have achieved our three objectives: having fun, making connections, and modeling collaboration. In addition, we ourselves have learned a great deal. ${ }^{24}$

The most frequent positive comment that students make on the written evaluation forms is that the blended classes are a welcome change of pace and, for that reason alone, are fun. The students' classroom behavior seems to authenticate this comment. Before the blended classes begin, students express curiosity about how they will work. Their curiosity seems mostly to reflect enjoyable suspense rather than fretful concern. During the blended classes students often laugh and appear engaged with both the material and each other. After the blended classes are over, we get many appreciative comments, most of which simply express a positive visceral response.

We do not deprecate either the need for students to have fun or the role that a simple change in instructional approach plays in making law school fun. After the first few weeks of classes, law school can become a grind. The most creative and resourceful teacher ultimately carves out a classroom routine. To some extent, students like a routine; the familiarity can make fearsomely difficult legal material more manageable. Yet we believe it is also important for the classroom to have an element of unpredictability. Ideally, a course must follow a path that leads the student consistently to feel both safe and stimulated.

We think that the timing and the duration of the blended classes help our joint teaching effort walk the line between familiarity and novelty. We have consistently held these classes close to the end of the semester, while leaving at least a week for the two courses to be held again as separate courses. This timing lets first-year students become comfortable with each other and with us, and (with some priming from us) it also gives them something to look forward to. At the same time, the students have a chance to regroup before the semester ends. As a practical matter, first-year students get increasingly examfocused as the end of the semester approaches, and they have a hard time having fun. Indeed, change becomes threatening. We plan to continue scheduling the blended classes sometime between the ninth and twelfth weeks of a thirteen- or fourteen-week semester.

Besides the comment that the blended classes are fun, another frequent positive comment is that students appreciate studying material from the two different perspectives of constitutional law and property law. Many students who make this comment add that, by exposure to two different professorial perspectives, they learn the material better. In particular, some students say that they understand the assigned judicial opinions better after hearing both of us discuss them. Other students identify the benefit of joint teaching as making the material more relevant to the "real world" of legal practice.

We think that these comments reflect several dynamics. One may be a process of student recollection. Before they began law school, many students

24. How do your colleagues really teach? What goes on in other classrooms in your school that you could use to improve your own teaching skills? The 10 blended classes give each of us a chance to watch the other teach, and we both believe that we are much better teachers, individually, as a result of these joint class exercises. 
probably thought of the law as a fairly undifferentiated whole-a system, a web, or perhaps a blob-reflecting the messiness of legal disputes in the real world. Law school shatters that conception by dividing "the law" into discrete courses that reflect the law's own classification system. The blended classes may enable students to recall their earlier holistic conception. We would hope, of course, that the conception is more refined than it was before.

We do not believe, however, that this is the only dynamic underlying the students' comment that the blended classes help them relate law school to the real world. The subject matter of the blended classes, especially the topic of eminent domain, is one that many students encountered before entering law school. ${ }^{25}$ In addition, during the blended classes we draw extensively on our own past experiences as practitioners. This approach stems partly from a comedic impulse to highlight our differences. Our practice backgrounds emerge into the forefront when we present oral argument to the students in a case that one of us was actually involved in litigating. The point is that our joint teaching appears to serve the function of demonstrating that all legal disputes have two (or more) sides to them.

The third recurring positive comment is that we complement each other. Many students say that we work together amicably, blend our perspectives effectively, and share teaching responsibilities faithfully. They remark that we obviously enjoy working together, and they imply that they enjoy our obvious enjoyment. Students seem impressed by the way our collaborative teaching culminates in an exercise in which we argue opposite sides of an appellate case. We think the students learn an important message: that lawyers can be vigorous advocates while also being friends.

We believe that the joys of professional collaboration are reinforced by the mock appellate argument held in the last blended class. Students seem to experience this as a role reversal that allows them to judge the teachers. That is true not only for the students who play judges but also for the students on the sidelines, who are encouraged to critique our performance. In short, the appellate argument seems to help the students band together in a joint effort to judge teachers whom they usually perceive as judging them.

Joint teaching has had one major benefit that we did not expect and that, frankly, accrues to us rather than to our students. Joint teaching has reminded us how hard it is to work with someone else, but how many real rewards come from working with others. We need that reminder because being a law school teacher is such a solitary pursuit. We need to retain and develop our collaboration skills in order to help our students develop theirs. It is all too easy for law teachers to lose those skills and forget how important they are in law practice.

We would like to be able to end this part of the article by reporting hard empirical evidence that our students actually learn the blended material better than other material that we teach them, but we have no such evidence.

25. At the beginning of the first class on eminent domain, we often ask the students whether they or a family member has been involved in an eminent domain proceeding. We regularly get an affirmative response from more than 10 percent of the class. 
What we have instead are quite a few former students who claim that the blended classes were their favorite part of our courses. Similarly, many students who complete written evaluations at the very end of the blended classes tell us that we should continue them in the future. No student has ever suggested, either orally or in writing, that we should discontinue the blended classes. In light of the apparent benefits that we see in the blended classes, the benefits that we ourselves have enjoyed, and the benefits reported by the students, we fully intend to continue our joint teaching.

\section{Advice}

We believe that our joint teaching can be replicated successfully, and that successful replication does not depend on selecting the same topics that we chose for our blended classes. We do not mean to suggest, however, that even a modest joint teaching effort such as ours is easy to plan or implement. To the contrary, we have made many mistakes in our joint teaching over the past several years and, in response, we have made periodic revisions in our approach to the blended classes. In this part of the paper we offer some general advice.

Selection of topic to be covered. Pick a substantive topic that is a natural and obvious choice for joint coverage. Students should not have to strain to understand why the topic lends itself to examination in either of the two courses that are to be blended. If they have to strain to make the connection, they may suspect that it was chosen because it is a pet topic of one or both teachers. At the same time, the topic needs to be one that both teachers understand well. It is hard enough to learn to teach a topic jointly without also having to learn its substance.

Here are some possible joint topics for teachers of various subjects. These are merely suggestions. Other topics are almost certain to come to your mind, depending on what you teach.

\begin{tabular}{|c|c|}
\hline Substantive classes & Possible joint subjects \\
\hline Property/Constitutional Law & Eminent domain \\
\hline Torts/Property & Nuisance law \\
\hline Contracts/Property & $\begin{array}{l}\text { Statute of frauds; leases; land } \\
\text { contracts }\end{array}$ \\
\hline Environmental/Administrative Law & Administrative Procedures Act \\
\hline Equity/Trust Law & Various topics \\
\hline Real Estate Transactions/Tax & $\begin{array}{l}\text { Tax consequences of real estate } \\
\text { transactions }\end{array}$ \\
\hline Torts/Contracts & $\begin{array}{l}\text { Express contractual assumption of } \\
\text { risk }\end{array}$ \\
\hline Torts/Constitutional Law & $\begin{array}{l}\text { Constitutional tort actions under } \\
42 \text { U.S.C. } 1983\end{array}$ \\
\hline Torts/Criminal Law & $\begin{array}{l}\text { Intentional torts (especially the } \\
\text { distinction between battery and } \\
\text { assault) }\end{array}$ \\
\hline
\end{tabular}


Scheduling of blended classes. Those who plan to teach a blended class should try to have exactly the same group of students. We have made some exceptions to this rule, but with deep misgivings. Specifically, in the first two years that we blended our classes, one of us had a transfer student who was not enrolled in the other course. These students were faced with the choice of either attending classes in a course in which they were not enrolled or missing about half of the joint classes. Transfer students should not be put at this disadvantage. In the last two years our school's registrar has made sure that we have the very same students.

Equally important, both teachers need to be able to attend all of the blended classes. In the most recent year in which we taught together, Seamon missed two of the blended classes to attend a conference. Although the students did not comment to us about his absence, which we explained to them beforehand, he felt distinctly like the odd person out on his return. Perhaps students benefit from seeing one colleague cover for the other, but it detracts from the students' experience of the blended classes as a true joint effort.

We recommend that both teachers and all students be able to attend all of the blended classes if you wish to use the model that we have described here. But it is certainly possible that other variations might work. For example, you could visit a colleague's class, and in turn that colleague could visit your class. We have not yet experimented with other models, but we hope that our experiment with joint teaching will prompt others to experiment using variations suited to their situation.

Coordination and preparation. We cannot overemphasize the importance of advance preparation to ensure that in every blended class session both teachers understand their own responsibility in that session, and there are no unexplained inconsistencies in what they say. ${ }^{26}$ As we've said, students appear to enjoy professorial debate about issues in the gray area, but they hate getting what seem to be conflicting versions of black letter law. And they seem to attribute such conflicts to either lack of adequate preparation or substantive incompetence.

The blending of classes thus increases not only each teacher's time in the classroom but also the preparation time. We have found that it is especially useful for both teachers to reserve time immediately before and immediately after each blended class for planning and debriefing.

Clear advance explanation of the students' responsibility for blended material. There is only one negative comment on the blended classes that we consistently receive. Every year, at least two or three students say that they do not fully understand what they need to know from the blended classes for the exam. As we mentioned, we take turns testing the blended material. Although we tell students at the beginning of the semester which of us will test the blended

26. It is hard enough for one person to make up her mind about what to teach and how to teach it. It probably is more than twice as hard for two people to be of one mind on those scores. 
material, some students seem to doubt that Professor Spitz will test them on principles that Professor Seamon discussed, or vice versa. Other students have suggested that it was a "surprise" that Professor Seamon had true "property issues" on the Constitutional Law exam. Finally, many students recognize that we use different exam formats. For that reason, we think, they have trouble imagining what form the question on the blended material will take.

We know that we need to address this concern more effectively in the future, but we have not figured out the best way to do it. ${ }^{27}$ We may respond to it by discussing with the class how the blended material has been tested in prior years. We welcome suggestions about this, as well as on every other aspect of our joint teaching effort. ${ }^{28}$

One of the characters in Marcel Proust's Remembrance of Things Past is able to grasp a significant event only by thinking of it "a little at a time." Similarly, in legal education we try to help our students gradually to construct a foundation for learning legal substance and skills and then to build on that foundation. To do that, though, we have traditionally thought it necessary to break the law into pieces, divorcing legal substance from legal skills and subdividing the substance of the law into many different substantive courses. Following tradition, we also assign individual teachers to teach individual courses, and they assign individual grades to each student. As necessary as these divisions may be, it is equally necessary to help students learn the interconnectedness of the law, and the connection between its practitioners, before they graduate. We believe that this learning process can itself be accomplished "a little at a time."

Try a week or two of joint teaching with a faculty colleague. We bet that, just like us, you will enjoy it immensely, and so will your students.

27. In addition to the concern discussed in the text-i.e., our concern to explain to students as clearly as possible how we will assess their learning of the blended material--a separate concern that is at least equally important is the suitability of our method of assessment, the traditional end-of-semester exam. We welcome suggestions on that aspect of a joint teaching effort (as we do on all other aspects).

28. If you do decide to do some joint teaching as a result of this article, or if you are already doing this type of teaching, we would truly enjoy hearing from you about your experiences and your suggestions. 